\title{
Collocation and Connotation of Indonesian Word Hitam (Black)
}

\author{
A Setyawan $^{1}, \mathrm{~T}$ Suhardiyanto ${ }^{3}, \mathrm{~S}$ Darmojuwono ${ }^{3}$ \\ \{1aan.setyawan@ui.ac.id, ${ }^{2}$ totok.suhardijanto@ui.ac.id, ${ }^{3}$ setiawati.darmojuwono@ui.ac.id\} \\ ${ }^{123}$ Faculty of Humanities, Universitas Indonesia
}

\begin{abstract}
This article deals with the collocation of Indonesian word 'hitam' (black) containing connotative meaning. Hitam is defined as the color of charcoal in the Great Indonesian Dictionary, whereas the meaning of hitam in its daily use has another meaning that does not explain color. This study uses the corpus linguistic approach. Data is obtained from the Indonesian Web corpus contained in the Sketch Engine. The minimal frequency was set at three and the minimal score of LogDice at three. The results of this study show eighteen forms of black collocation which have connotative meaning. The eighteen forms of black collocation are used in six semantic preferences, namely (1) occult, (2) politics and government, (3) history, (4) economy and business, (5) crimes, (6) and martial arts. There are four connotative meanings of hitam found in this research; (1) evil, for example in the expression of ilmu hitam 'black magic', (2) dangerous, such as daftar hitam 'black lists', (3) bad, such as sejarah hitam 'black history', and (4) illegal, such as kampanye hitam 'black campaign'.
\end{abstract}

Keyword: collocation, connotation, semantic preference, semantic field, black

\section{Introduction}

The denotative meaning of color is lexically related to the identity of the referent. Putih 'white', for instance, in Indonesian word refers to the identity or the feature of the cotton's color, while in English it refers to the snow [1]. The color has a vital role in human life. In its use, color not only shows the spectrum of the visual color, but also to symbolize other things. For example, pink symbolizes love and white symbolizes purity. The number of color lexicon between one language and another is different. Therefore, how to determine color between one person and another are not the same. Japanese, for example, has the terms ao or aoi means blue. The color of sky and sea are $a o$. However, the term $a o$ is also used to describe grass, forests, traffic lights and raw tomatoes [2].

Not all color lexicons are used by humans. [3], for instance, found that several color lexicons in Indonesian are not used in daily life, such as beranang 'red', biring 'cherry red', pirau 'grey', indranila 'peacock blue', and jerau 'maroon'. The fact that not all of the color lexicons used by speakers of the language indicates that there are basic colors as the prototype colors in society. Humans, basically, will perceive colors if they see color waves between 390 to 790 nanometers $(\mathrm{nm})$. Each basic color can be identified by the color wavelength. 
Table 1 Wavelength for the various colors

\begin{tabular}{ll}
\hline Colors & Wavelength \\
\hline red & $790-630 \mathrm{~nm}$ \\
orrange & $630-580 \mathrm{~nm}$ \\
yellow & $580-560 \mathrm{~nm}$ \\
green & $560-480 \mathrm{~nm}$ \\
blue & $480-420 \mathrm{~nm}$ \\
violet & $429-390 \mathrm{~nm}$ \\
\hline
\end{tabular}

Humans have the same biological basis that makes it possible to see color waves, unless there are biological abnormalities.

Color not only has denotative meaning, but also connotative meaning which is the first time is revealed by Mill [4] by stating "the white word, denotes all white things, as snow, paper, the foam of the sea, etc., and implies, in the language of the schoolmen, connotes, the attribute of whiteness". Color is often associated with cultural connotations. [5] shows that red in Chinese's culture is regarded as the most important color because it is considered to have the meaning of luck. Therefore, eventful activities such as in marriage is using red color. In contrast, the meaning of red in American culture tends to have dangerous or negative meanings. [6] gives examples related to hazards in America marked with red, for example on entry bans, traffic signs, and signs of terrorist attacks. This illustrates the cultural connotations of the color belonging to one culture and other cultures have different meanings.

Studies related to color generally discuss many aspects about connotation and color classification. For example, Xing (2008), He, and Allan examine the meaning of color connotations in Chinese and English. In addition, many studies on color also discussed the color classification in a language, for example [7] who investigated the classification of color on the Betawi people and Darmojuwono [8], [9] who examined the effect of semantic classification on human perception. The research that still very rarely studied is examining colors from the aspect of collocation. What words are collocated with, for example, black and what meaning is realized from the results of the collocation. The form of black coffee, for example, indicates the color of coffee is black. However, black magic does not mean the color of magic is black.

\section{Research Method}

The data were generated from Sketch Engine with the Indonesian web corpus for entry hitam. The collocates are obtained from Word Sketch. Word Sketch contains a list of collocations that have been automatically categorized based on the grammar class. The Word Sketch selected are next_left and noun_left. The author determines the minimum number of frequencies is three with a minimum score of LogDice at three. Word Sketch uses the LogDice formula to determine the kolokat-kolokat. "In Sketch Engine, the tool to use for collocations is the word sketch. The strength of collocation is expressed by the log score" [10]. Sketch Engine actually also provides other calculation tools such as MI, MI3, and T-Score to calculate collocation manually. Researchers use LogDice as used by default by Word Sketch with the reason to look for forms of collocation that are exclusive / unique. The author deliberately chose all forms of collocation with a minimum score and frequency with the aim that all forms of black collocation netted all. From the collocations generated, further searching was carried out for any collocates of hitam within a 5-word span both to the right 
and left. For instance, based on the first search kambing was found to be a collocate of hitam that forms kambing hitam. The second search was then carried out for any collocates of the construction kambing hitam within a five-word span to the right and left [11], [12].

\section{Results And Discussion}

There are eighteen collocations of black whose meanings are not related to color waves, but used to explain something bad, evil, and dangerous things. These meanings appear at least in six semantic fields (1) the occult, (2) politics and government, (3) history, (4) economy and business, (5) martial art, and (6) crimes.

Table 1 Collocations of Black

\begin{tabular}{ll}
\hline Collocation & Collocation \\
\hline 1. ilmu hitam (black magic) & 10. pengusaha hitam (black businessman) \\
2. dunia hitam (black world) & 11. konglomerat hitam (black conglomerate) \\
3. golongan hitam (black group) & 12. sejarah hitam (black history) \\
4. daftar hitam (blacklist) & 13. penyihir hitam (black witch) \\
5. catatan hitam (black record) & 14. lembah hitam (black valley) \\
6. organisasi hitam (black organization) & 15. aliran hitam (black stream) \\
7. kampanye hitam (black campaign) & 16. dunia hitam (black world) \\
8. propaganda hitam (black propaganda) & 17. potret hitam (black portrait) \\
9. sihir hitam (black magic) & 18. jin hitam (black genie) \\
\hline
\end{tabular}

\subsection{Semantic Preferences of Black}

\section{a. Occult}

Hitam is used to explain the phenomena related to magical power or the occult world such as ilmu hitam 'black magic', penyihir hitam 'black wicked, jin hitam 'black genie', and sihir hitam 'black magic'. All these collocations have negative associations. Ilmu hitam is used for crimes or intended to harm people. This can be proven by collocates such as santet 'withcraft', sihir 'magic', and guna-guna 'withcraft'

(1) Ilmu yang dibenci ialah seperti ilmu sihir, ilmu hitam dan ilmu guna-guna

(2) Program khusus penanganan gangguan jin \& ilmu hitam yang diadakan setiap kamis, jumat, sabtu \& minggu

Based on the verbs collocating with ilmu hitam shows that it is learned and practiced in life. It can be proven by the verbs collocating with ilmu hitam such as mengamalkan 'to practice', mengajar 'to teach', mempelajari 'to learn', menggunakan 'to use', and memiliki 'to possess'

Table 2 Semantic Preference of ilmu hitam

\begin{tabular}{ll}
\hline $\begin{array}{l}\text { semantic } \\
\text { preference }\end{array}$ & Supranatural \\
\hline nouns & $\begin{array}{l}\text { sihir 'magic', santet 'withcraft', penganut, 'adherent' guna-guna 'withcraft', jin } \\
\text { 'jinn' } \\
\text { verbs }\end{array}$ \\
$\begin{array}{l}\text { mengamalkan 'to practise', mengajar 'to teach', mempelajari 'to learn', } \\
\text { menggunakan 'to use', memiliki 'to possess }\end{array}$ \\
\hline
\end{tabular}




\section{b. Politics and Government}

The most collocation of hitam is commonly found in the political and governmental domains. All meanings formed in this field are also negative. Kampanye hitam 'black campaign' and propaganda hitam 'black propaganda' are both have negative meanings. Kampanye hitam is a campaign by bringing down political opponents with various methods even though it violates the rules and norms in force.

(3) Foke berjanji tak akan melakukan kampanye hitam.

(4) SBY masih diterpa kampanye hitam.

The verbs collocating with kampanye hitam show intentional actions, such as menyebarkan 'to spread', mengakui 'to admit', and melakukan 'to do' which indicate that the activities of kampanye hitam are deliberate actions. The semantic preference of black campaign is related to politics which describes something bad, as evidenced by the collocate tersangka 'suspect'. Propaganda hitam is propaganda that is not based on the real facts and used to influence the wider community about what is being propagandized.

(5) Semua radio ini menyebarluaskan langsung propaganda hitam yang langsung menuding PKI dan Subandrio dalang peristiwa $G 30 \mathrm{~S}$

(6) Antara lain dengan propaganda hitam bahwa Khilafah adalah negara otoriter yang nonakuntable (anti-kritik)

Propaganda hitam is used by certain groups to defeat other parties proven by verbs that collocate with propaganda hitam such as mempergunakan 'to use', menyebarluaskan 'to spread', and dilancarkan 'to be launched'.

Table 4 Semantic preference of Propaganda Hitam

\begin{tabular}{ll}
\hline $\begin{array}{l}\text { semantic } \\
\text { preference }\end{array}$ & politics and government \\
\hline nouns & $\begin{array}{l}\text { desas-desus 'rumors', isu 'issues', PKI, khilafah, militer 'military' } \\
\text { verbs }\end{array}$ \\
$\begin{array}{l}\text { menyebarluaskan 'to disseminate', mempergunakan 'to use', dilancarkan 'to be } \\
\text { launched', termakan 'to be consumed' }\end{array}$ \\
\hline
\end{tabular}

\section{c. History}

Hitam is also used to explain the bad history that happened in the past. This is reflected in the collocation forms such as sejarah hitam 'black history' and catatan hitam 'black records'. Sejarah hitam is a historical event that was not very good in the past and has become a concern of many people such as the occurrence of massacres, corruption, and occupation.

(7) Penahanan Bibit dan Chandra, tegasnya, merupakan sejarah hitam penegakan hukum dan sekaligus kemenangan bagi koruptor

(8) Indonesia telah mengalami sejarah hitam yang sangat panjang, 350 tahun bangsa ini berada dalam cengkraman kuku kaum imperialis

The corpus shows that sejarah hitam mostly collocates with nouns such as bangsa 'nations' and negara 'countries' which shows sejarah hitam appears more in contexts related to the problems of the nation and state.

Table 5 Semantic Preference of Sejarah Hitam

\begin{tabular}{ll}
\hline semantic preference & history, politics and government \\
\hline nouns & bangsa 'nation', negara 'country', manusia 'human', \\
verbs & mempunyai 'to have', merupakan ', menjadi 'become' \\
\hline
\end{tabular}


Catatan hitam is used figuratively to describe a very bad event that happened in the past so that it is an important concern.

(9) Tragedi Trisakti, Semanggi I, Semanggi II menjadi satu catatan hitam bagi negara yang menggunakan pendekatan keamanan untuk membungkam rakyatnya

(10) Periode perang saudara ini sendiri dianggap menjadi awal catatan hitam dalam sejarah Kekaisaran Romawi

Catatan hitam shows more events that have occurred in the past which is indicated by many collocates with the word history.

\section{d. Economy and Business}

Hitam is also used to explain the perpetrators of bad economic activity as reflected in the collocations of pengusaha hitam 'black businessman' and konglomerat hitam 'black conglomerates'.bPengusaha hitam is someone who carry out their business activities contrary to applicable laws and regulations such as bribery, corruption, nepotism, and collusion.

(11) Setidaknya ada tiga indikasi dana haram; pengusaha hitam, asing, dan BUMN

(12) Korupsi, nepostime, kolusi yang setiap hari dilakoni oleh birokrat, parlemen, militer, polisi dan pengusaha hitam

The word pejabat 'official' is the most prominent collocated with pengusaha hitam which indicates a strong relationship between black businessmen and officials.

Table 6 Semantic Preference of Pengusaha Hitam

\begin{tabular}{|l|l|}
\hline semantic preference & Business \\
\hline nouns & pejabat 'official', dana 'fund', korup 'corrupt', oknum 'unscrupulous' \\
\hline verbs & menjadi 'to become', membuat 'to make' \\
\hline
\end{tabular}

Konglomerat hitam is rich people who carry on activities that are contrary to the law and harm the state, for example misappropriation of Bank Indonesia Liquidity Support (BLBI funds).

(13) Kasus BLBI yang melibatkan banyak konglomerat hitam

(14) Para konglomerat hitam telah menyebabkan kerugiaan negara hampir Rp 600 triliun

Semantic preference of konglomerat hitam appears in the domains of politics and government which show something bad because it also collocates with kasus 'cases', ulah 'acts', and preman 'thugs'. Konglomerat hitam also refer to more than one number, evidenced by collocating with large numbers of para 'collective marker $-s$ '(25).

\section{e. Martial Arts}

Hitam is also widely used to explain the martial world which is full of evil. This is reflected in the collocation of black such as aliran hitam 'black flow' and sinar hitam 'black light'.

Aliran hitam is used figuratively to refer to the group that carries out its activities for crime. In this context, aliran hitam has a correlation with aliran putih 'white flow' as two things that are opposite. Aliran hitam is for bad thing, whereas aliran putih is for good thing.

(15) Melihat hal ini, pentolan aliran hitam yang berjiwa kejam ini terkejut bukan kepalang

(16) tampaklah sebentuk rajah yang menandakan pemiliknya menganut ilmu kesaktian aliran hitam Prabu Sanghyang Cakradewa sangat kecewa mendapati kenyataan tersebut

Sinar hitam appears in the text of novel describing a ray which has power to hurt someone.

(17) Dua larik sinar hitam menderu memapaki Thian Ong, Bwe Hun dan Wiro Sableng

(18) Selarik sinar hitam yang menebar bau sangat busuk menyembur ke sekujur tubuh Ni Gatri 
The semantic preference of sinar hitam shows something bad as showed by the collocates such as menderu 'roaring' and menyambar 'grabbing' which show that sinar hitam is dangerous. This is reinforced by the nouns which also collocate with sinar hitam such as sambaran 'swoop' and gulungan 'coils'.

Table 7 Semantic Preference of Sinar Hitam

\begin{tabular}{|l|l|}
\hline semantic preference & martial arts \\
\hline nouns & $\begin{array}{l}\text { larikan 'beam', selarik 'a beam', sambaran 'strike', gulungan 'roll', } \\
\text { suara 'sound' }\end{array}$ \\
\hline verbs & $\begin{array}{l}\text { menggidikan 'to goose bump', menyambar 'to pounce', menderu 'to } \\
\text { rumble', mengeluarkan 'to pull out', melihat 'to see' }\end{array}$ \\
\hline
\end{tabular}

\section{f. Crimes}

The life referred to here is a general life problem experienced by humans, for example doing good or evil. Black is used to explain bad life as reflected in the form of collocation of the black world and black valleys. Dunia hitam describe an activity carried out by someone related to crime or activities that are contrary to the laws and norms such as drugs and prostitution.

(19) Tidak sedikit para remaja yang terjerumus ke dunia hitam karena pengaruh teman pergaulannya

(20) Dia terjun ke dunia hitam pelacuran

The verb mostly collocate with dunia hitam is terjerumus 'fallen' and terjun 'plunged' which indicates that subjects who experience dunia hitam generally do not intend to be in the dunia hitam and want to get out. Dunia hitam also appears in the martial arts which is related to evil.

Table 8 Semantic Preference of Dunia Hitam

\begin{tabular}{|l|l|}
\hline semantic preference & Crimes \\
\hline nouns & tokoh-tokoh 'figures', mistik 'mystic' \\
\hline verbs & $\begin{array}{l}\text { terjerumus 'to fall', terjun 'to plunge', bertemu 'to meet', terkenal 'to } \\
\text { be known' }\end{array}$ \\
\hline
\end{tabular}

Lembah hitam is used metaphorically to describe activities that should not be experienced, but it happened. The activity is actually not desirable because it deals with activities that are contrary to applicable laws and community norms. Therefore, it generally collocate with the verb terjerumus 'to fall'.

(21) terjerumus ke dalam lembah hitam pelacuran

(22) ada juga yang terjebak di dalam lembah hitam yaitu berprofesi sebagai pencopet cilik

In addition to the verb terjerumus, there are also verbs terjebak 'to be trapped', terseret 'to be dragged', and terbawa-bawa 'to be carried away' which all show undesirable activity by subjects who have fallen into lembah hitam.

\subsection{The Connotation Meanings of Hitam}

From the several collocations of hitam that have been described previously, it shows that hitam is not related to the color wave, but it is used to categorize events related to human life 
which--in general--show negative things. There are at least four connotation meanings of hitam in Indonesian word. First, hitam means evil that is reflected in the collocation such as kampanye hitam 'black campaigns', propaganda hitam 'black propaganda', sihir hitam 'black magic', jin hitam 'black genie' and black magicians. Based on these forms, the most are in collocation with the semantics fields of martials and the occult world. Second, black means dangerous. This is reflected in collocation forms such as black organizations, black rays, black lists and black notes. Third, black means bad or dark as reflected by collocation forms such as black history, black world, black valleys, and black portraits. The last is black means illegal as reflected by pengusaha hitam and konglomerat hitam.

\section{Conclusion}

Hitam is not only with regard to color, but also used by humans to categorize something bad. The use of hitam in many fields related to human life shows that hitam is very close to humans. Negative events are more easily remembered by humans than positive events. Kredit macet 'bad credit', dunia hitam pelacuran 'a black world of prostitution', and sejarah hitam pembantaian massal 'the black history of mass murder' are examples of negative events experienced by humans. From this study also shows that hitam has some connotation meanings. Therefore, it is fitting for KBBI to include the connotative meaning of hitam. This research shows that black has at least four connotative meanings namely evil, dangerous, illegal, and bad [13].

\section{Acknowledgment}

This article is part of the author's thesis that received a research grant from the University of Indonesia. Therefore, the researcher thanked the University of Indonesia for the research grants given.

\section{References}

[1] B. P. dan P. B. Kemendikbud RI, "Hasil Pencarian - KBBI Daring," Badan Pengembangan dan Pembinaan Bahasa, Kementerian Pendidikan dan Kebudayaan Republik Indonesia. 2016.

[2] F. Conlan, " Searching for the semantic boundaries of the Japanese colour term 'AO'," Aust. Rev. Appl. Linguist., 2003.

[3] S. Darmojuwono, "Pengaruh Klasifikasi Semantis Bidang Warna Kepada Persepsi Manusia," Linguist. Indones., vol. Desember, pp. 333-43, 1987.

[4] J. S. Mill, A System of Logic, Ratiocinative and Inductive. 2011.

[5] G. He, "English and Chinese Cultural Connotation of Color Words in Comparison," Asian Soc. Sci., 2009.

[6] K. Allan, "The connotations of English colour terms: Colour-based X-phemisms," J. Pragmat., vol. 41, no. 3, pp. 626-637, 2009.

[7] S. Budiono, "Klasifikasi Warna Masyarakat Betawi di Marunda , Jakarta Utara Volume 4 Nomor 2 Edisi Desember 2016 ISSN 2354-7200 JURNAL ILMIAH KEBAHASAAN DAN KESASTRAAN Sirok Bastra Jurnal Kebahasaan dan Kesastraan Volume 4 Nomor 2 Desember," no. December 2016, 2018. 
[8] S. Darmojuwono, "Language, culture, and social cognition," Wacana. 2016.

[9] S. Darmojuwono, "Pengaruh Klasifikasi Semantis Bidang Warna Kepada Persepsi Manusia," Linguist. Indones., vol. Desember, pp. 333-43, 1987.

[10] F. Conlan, " Searching for the semantic boundaries of the Japanese colour term 'AO'," Aust. Rev. Appl. Linguist., 2003.

[11] L. J. Moleong, Metodologi Penelitian Kualitatif. Bandung: Remadja Karya, 1989.

[12] M. Tampubolon, "Figurative Language in the Toba Batak Saur Matua Ceremony," Linguist. Terap., vol. 14, no. 2, pp. 122-131, 2017.

[13] K. Saddhono, "Language and superdiversity: Indonesians knowledging at home and abroad. By Zane Goebel." Soc. Stu. vol. 12 no.1 pp. 113-118, 2018 